Suratminto, Lilie. 2006. "Komunitas Kristen masa VOC di Batavia dilihat dari batu nisannya; Sebuah kajian semiotik dan analisis teks". Disertasi, Fakultas Ilmu Pengetahuan Budaya, Universitas Indonesia, Depok.

Stuart Robson, Arjunawiwäha; The marriage of Arjuna of Mpu Kanwa. Leiden: KITLV Press, 2008), xiii + 208 pp. (Blibliotheca Indonesica 34). ISBN 978-906718-321-5. Price: EUR 24.90 (soft cover).

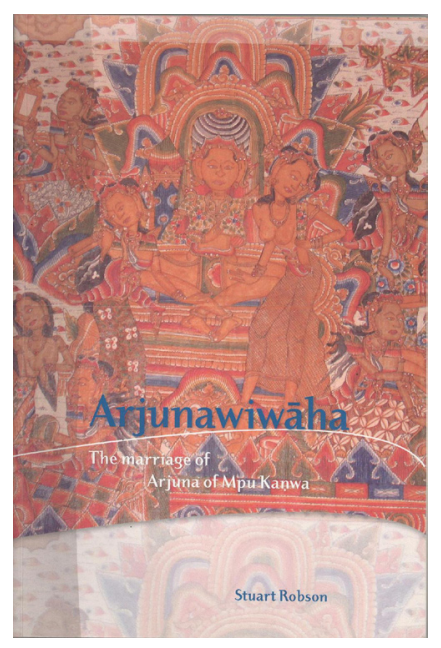

Dick van der Meij

Center for the Study of Religion and Culture UIN Syarif Hidayatullah, Jakarta dickvdm2005@yahoo.com

Only surpassed in popularity and ubiquity by the nineteeth century Kakawin Rāmāyaña, Mpu Kanwwa's eleventh century Old Javanese Kakawin Arjunawiwāha is immensely popular in Bali. It probably was also popular in ancient Java where originates from, although proof of that is unfortunately impossible to establish. Over the ages, the text has been transmitted in countless palm leaf manuscripts (lontar) in Bali and Lombok which at present are preserved in any collection of Indonesian manuscripts that is worthy of its name, in Bali, elsewhere in Indonesia and abroad. In Bali and among the Balinese population of adjacent Lombok, many private individuals own a copy too and it is safe to say that the number of manuscripts containing this kakawin is very large indeed.

Many manuscripts are complete, but many are not due to damage but also because they were never meant to be complete and contain fragments, usually of one or more cantos. Many manuscripts are provided with Balinese glosses while illustrated palm leaf manuscripts (prasi) have also been made of this text.

There is a West Javanese, Central and East Javanese (including Madura), and especially Balinese tradition (including Lombok) of the contents of the text: Arjuna has to vanquish the demon Niwātakawaca and after succeeding he gets as reward to replace Indra as King of Heaven and to have the marital pleasures of seven heavenly ladies. Time and again, in Bali, illustrations depicting scenes of this text were made on canvas, behind glass, on temple walls and in woodcarvings and these illustrations are found all over the island. Especially in the so-called Kamasan Wayang style the Arjuna Wiwaha is literally everywhere. The scene most often depicted is that of Arjuna's temptations at the hands of the seven lovely heavenly nymphs, and this is indeed the scene that adorns the cover of this book. In Bali, the text is moreover sung during 
so-called pepaosan sessions and pepaosan reading clubs are found all over the island in hamlets, villages, and urban communities while contests are held at the sub-provincial and provincial levels, often sponsored by enterprises or the regional government.

In the past, in Java, the text was transposed to modern verse forms (sekar ageng, tembang macapat) and to prose, usually under the title Mintaraga or simply Wiwaha while the text is also part of the wayang purwa repertoire in Java and wayang parwa in Bali. The text has often been translated into Indonesian and Balinese and is now in Bali freely available in an edition in Balinese script in Old Javanese with corresponding Balinese integral translation. In Java the textual tradition has stopped.

In Bali there is no way to escape the text and it is therefore lamentable that Robson has failed to devote any space to the Balinese aspect of the textual tradition, the more so since the eight manuscripts he used for this edition all originate from the Island (pp. 1, 34).

Using material from Java, I. Kuntara Wiryamartana made the last scholarly translation into Indonesian in 1990 while Poerbatjaraka translated the text into Dutch in 1926. The aim of the present translation "is simply to make the text available once more" and to offer "an introduction which places this poem in its historical and literary context and explains some of the concepts that form its background so that the reader has a better chance of appreciating its qualities and grasping its significance" (p. vii). The reader will understand that Robson indeed had occasion to explain only "some" concepts since the introduction only measures 36 pages which, clearly, is not enough, the more so as five pages have been used for a canto by canto synopsis of the story. Rather than calling his work a translation, Robson prefers to call it an "interpretation" which is moreover to be regarded as a guide to the understanding of the original ( $p$. 1). This is a very clever way to circumvent criticism on the literary merits of the translation itself, more on which below. I hasten to say, however, that Robson is acutely aware of the difficulties of translating kakawin as attested by his article in the Bijdragen voor Taal-, Land-en Volkenkunde of 2001 and his remarks in the Bhomāntaka edition of 2005. Translating kakawin is difficult and presenting a readable and literarily satisfactory translation is another thing altogether.

The book is basically an old fashioned text edition with the Old Javanese text on the left page and the corresponding English translation on the right. Text editions of Old Javanese kakawin are difficult to make and extremely time consuming and we can only marvel at Robson's patience that he has been able to devote part of his time over more than ten years to produce this book; there have been instances in the past of scholars who attempted to make a text edition of a kakawin but unfortunately dropped the project for whatever reason (I seem to remember that E.M. Uhlenbeck once planned an edition of the Ràmāyana but unfortunately never did and if he ever indeed intended to make one, we are still eagerly awaiting Peter Worsley's edition of the Sumanasāntaka). As I mentioned before, the number of scholars with 
the knowledge and the interest to produce this kind of editions is becoming dangerously small (Van der Meij 2006: 400 note 2).

Robson is one of the most prolific students of Old Javanese. His role in Zoetmulder's Old-Javanese-English dictionary is in my view completely insufficiently appreciated and he has translated the Deśawarnana (Nägarakrtägama, 1995), the Bhomāntaka (with Teeuw 2005) and the Kunjarakarna Dharmakathana (also with Teeuw 1981) and he was involved in the translation of the Śiwarätrikalpa (Teeuw et al., 1969). He also translated the Middle Javanese Panji story Waybay Wideya (1971) and the modern Javanese Wédhatama (1990). The present edition is completed with Variant readings, Comments, List of personal names, List of meters, and a Bibliography.

\section{THE INTRODUCTION}

Robson starts with speculating about the author of this work, Mpu Kanwa and more speculation is to follow. There is a lot of speculation in the world of Old Javanese literature, its origins and the reliability of its authorship and the dates of composition, and the numerous conjectures and probabilities are starting to annoy me. I fear that by lack of proof we have precious little understanding of what really happened in the dark ages of Javanese history and that all our speculations are just that, speculations. That is why I find it so remarkable that the present situation in Bali is not taken as point of departure and that this text, yet again, is merely seen within the framework of what it can teach us about the history and culture of ancient Hindu-Buddhist Java. I fail to see why ancient Java would be more interesting than present day Bali, especially as present day Bali is only a number of flying hours away. The deplorable lack of a sound literary methodology in the study of this history based on the available manuscripts is also an attributing factor in the perpetuation of this speculative kind of scholarship, in which Robson was trained at Leiden, as, I might add, was I.

The rest of the introduction is devoted to the origins of the text, kakawin and kavya, the structure of the text, theme and significance, etcetera.

\section{THE TRANSLATION}

Even though Robson humbly calls his translation a guide to the contents of the text, reading this guide should nevertheless be an enjoyable exercise. Everybody has to read so much nowadays that a book that becomes annoying will simply not be read. As so often reiterated, the text is beautiful, so why not honor it with a beautiful English rendering? Alas, I fear that Robson has relinquished his literary capabilities in favor of scholarship.

Translating a distant text is, of course, also hazardous because of our interpretation which sneaks its way into the translation whether we want it or not. Sometimes this leads to possible misinterpretation or misunderstanding. For instance, canto 1, stanza 11, line 3: akweh tâpsaracetikā milu tuhun kapwângiring doh kabeh, is translated as: 'Many were the hand-maidens in attendance, though they followed at a respectful distance'. 
Now, the word 'respectful' is not in the original Old Javanese. Using this word would lead us to think that the hand-maidens were respectful of the nymphs, which may be so but still the author would have wished to indicate some differences in the status of both, would he not? This sentence follows a description of the beauty of the nymphs and that they flew off to meet Arjuna "softly as a gentle breeze" (same stanza, line 2). Using 'respectful', which for a distant to a person of higher rank could still be actually quite near, would imply that the hand-maidens would be as delicate and quiet as their mistresses, which would diminish the qualities of those same mistresses and is therefore hard to conceive. When 'respectful' were not used, we might simply surmise that all (kabeh, not translated) the hand-maidens were following their mistresses at a distance (doh) (as the text says) and thus not disturbing their noiseless approach in any way. Am I interpreting too far here, or does Stuart? (Actually, these kinds of interpretation arguments are the most enjoyable part of translating this kind of texts!)

Another example is the start of canto 24 where it is completely incomprehensible what is going on. In one sentence is said that people still remained on the mountain after having been fiercely attacked and in the next is related that all of those who had not been eaten by demons and giants had been carried off. So where do the people who remained on the mountain come from? The second stanza relates that the king of Manimāntaka arrives and tied them up and pursued them. One would wonder why the poor soles who outlived the attack by the demons should have been so harshly treated by their own party? I am sorry to say that the portent of this scene escapes me completely and therefore some explanation would have been helpful.

Another confusing feature is the use of proper names. The Old Javanese text for example mentions God Śakra, but in the translation Robson translates him as Indra? Why? Arjuna is referred to in the text as Pārtha, Arjuna, Phalguna, Dhanañjaya etc. which he does not all change into Arjuna while when he is intended in the same stanza (for example, canto 1, stanza 6) by the use of two different names the text becomes rather confusing for a non-initiated reader, who has to refer to the list of names in the text to find out that Arjuna indeed has many names. I think I would have preferred to keep the original names throughout and would have made some remark or other in the introduction about this feature where some specifics of the translation are discussed.

Many difficulties in the translation are further discussed in comments at the end of the text. However, Robson has not been too consistent in his commentary as many italicized words in the translation remain unexplained and that is a pity. An uninitiated reader without knowledge of Old Javanese would have difficulty understanding canto 3 stanza 13 line one: 'One only wore her hair in the gĕlung grĕt style, languidly wearing a sĕkar taji and gleaming tutup gĕlung'. What to make of 'siddha nature' in canto 7 stanza 8 line 2, 'your sect is the wiku' in canto 8 stanza 3 line 3 , Now I know that an apsari is a nymph, but to leave the male equivalent apsara untranslated in canto 12, stanza 9 line 1 would mean that everyone should know this, but is this so? 
Looking at the above, Robson's efforts to present us with this 'guide' are hopefully not his last enterprise with this text. I would certainly look forward to a more literary translation of which I know that Stuart will be more than capable of making one. We should rejoice that the complete text is now available in English for a scholarly audience and let us hope it will find its way to a wider audience than Old-Javanists alone.

\section{REFERENCES}

Kuntara Wiryamartana, I. 1990. Arjunawizwāha; Transformasi teks jawa kuna lewat tanggapan dan penciptaan di lingkungan sastra jawa. Yogyakarta: Duta Wacana University Press.

Poerbatjaraka, R.Ng. 1926. "Arjuna Wiwaha, tekst en vertaling", Bijdragen tot de Taal-, Land-en Volkenkunde 82: 181-305.

Robson, Stuart. 1971. Waybay Wideya; A Javanese Panji romance. The Hague: Nijhoff. (Bibliotheca Indonesica 6).

Robson, Stuart. 1990. The Wédhatama; An English translation. Leiden: KITLV Press. (Working Papers 4).

Robson, Stuart. 1995. Deśawarnana (Nāgarakrtāgama). Leiden: KITLV Press. (Verhandelingen 169).

Robson, Stuart. 2001. 'On translating the Arjunawiwāha', Bijdragen tot de Taal-, Land- en Volkenkunde 157: 35-50.

Teeuw. A. et al. 1969. Śiwarātrikalpa of Mpu Tanakuì; An Old Javanese poem, its Indian source and Balinese illustrations. Leiden: KITLV Press. (Bibliotheca Indonesia 3).

Teeuw, A. and S.O. Robson (eds). 1981. Kuñjarakarna Dharmakathana; Liberation through the law of the Buddha; An Old Javanese poem by Mpu Dusun [...]. Leiden: KITLV Press. (Bibliotheca Indonesica 21).

Teeuw, A. and S.O. Robson (eds). 2005. Bhomāntaka; The death of Bhoma. Leiden: KITLV Press. (Bibliotheca Indonesica 32).

Van der Meij, Dick. 2006. "Review essay; Latest editions of Indonesian classical texts", Bijdragen tot de Taal-, Land-en Volkenkunde 162: 397-405. 